\title{
Impressive bullous reaction to mosquito bites
}

\author{
Sara Mai, Siham Mansouri 도 , Nadia Ismaili, Karima Senouci
}

Dermatology, Chu Ibn Sina, Rabat, Morocco

\section{Correspondence to}

Dr Siham Mansouri;

siham-mnsr@hotmail.fr

Accepted 30 October 2019

\section{DESCRIPTION}

A 34-year-old female patient, with no medical history, presented to our department with large blisters arising from pruritic erythematous swollen patches after mosquito bites. Medical examination revealed multiples tense perfectly hemispherical bullas, sized from 1 to $2 \mathrm{~cm}$, on the inner side of the left knee and thigh overlying large round urticarial plaques (figure 1). The patient stated that she had never experienced a similar reaction to mosquito or any kind of insect bite before. The rest of examination was normal. A complete blood count was performed with no notable abnormalities. The bullas were aseptically pierced and the patient received antihistamines along with local corticosteroids and antiseptics.

Local reactions to mosquito bites are very common. They generally manifest as pruritic papules that disappear in few days. Severe reactions, mainly local but also systemic in rare cases, are possible

Common skin manifestations to mosquito bites are either instant hypersensitivity reactions mediated by mast cells resulting in urticarial papules that usually disappear in less than $20 \mathrm{~min}$, or delayed hypersensitivity reaction with pruritic papules that resolves in few days. ${ }^{1}$

More unusual local reactions have been described such as vesicular or purpuric or bullous reactions, as

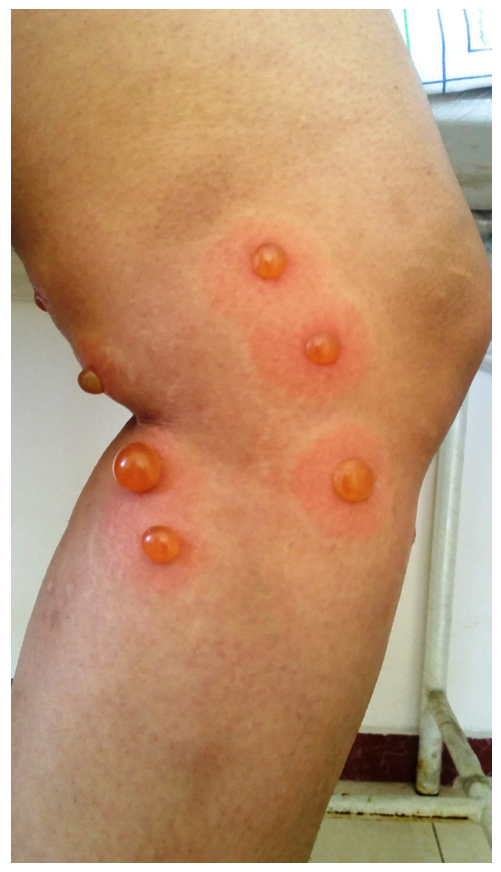

Figure 1 Several tense bullas overlying urticarial plaques on the leg.

\section{Learning points}

Skin reactions to mosquito bites are very variable.

- Bullous reactions are the most uncommon and can be rather impressive.

- This benign condition can sometime be the first manifestation of Epstein-Barr virus-associated natural killer/T lymphoproliferative diseases. Therefore, long-time follow-up is essential for these patients.

it was the case in our patient. Systemic reactions are very rare and include fever, angioedema, nausea or even anaphylactic choc. ${ }^{23}$

Only cases with systemic reactions should be considered as allergic to mosquito bites. Several risk factors to these severe reactions have been described such as young age, change of usual environment (immigrants, travellers) and Epstein-Barr virus-associated natural killer/T lymphoproliferative diseases. ${ }^{45}$

Prevention is the most important part of the treatment. Antihistamines and local cortisteroids may decrease the intensity of the skin reactions. Systemic symptoms should be treated according to their severity. ${ }^{4}$

Contributors SaM: contributed in the design, conception and drafting of the paper, participated in the patient's care. SiM: contributed in the design, conception and drafting of the paper. $\mathrm{NI}$ : made the corrections. KS: made the therapeutic decisions and supervised the writting process.

Funding The authors have not declared a specific grant for this research from any funding agency in the public, commercial or not-for-profit sectors.

Competing interests None declared.

Patient consent for publication Obtained.

Provenance and peer review Not commissioned; externally peer reviewed.

ORCID iD

Siham Mansouri http://orcid.org/0000-0002-5140-7607

\section{REFERENCES}

1 Peng Z, Simons FER. Mosquito allergy: immune mechanisms and recombinant salivary allergens. Int Arch Allergy Immunol 2004;133:198-209.

2 Peng Z, Beckett AN, Engler RJ, et al. Immune responses to mosquito saliva in 14 individuals with acute systemic allergic reactions to mosquito bites. J Allergy Clin Immunol 2004;114:1189-94.

3 McCormack DR, Salata KF, Hershey JN, et al. Mosquito bite anaphylaxis: immunotherapy with whole body extracts. Ann Allergy Asthma Immunol 1995;74:39-44.

4 Peng Z, Simons FER. Advances in mosquito allergy. Curr Opin Allergy Clin Immunol 2007;7:350-4.

5 Sakakibara Y, Wada T, Muraoka M, et al. Basophil activation by mosquito extracts in patients with hypersensitivity to mosquito bites. Cancer Sci 2015;106:965-71. 
Copyright 2019 BMJ Publishing Group. All rights reserved. For permission to reuse any of this content visit https://www.bmj.com/company/products-services/rights-and-licensing/permissions/

BMJ Case Report Fellows may re-use this article for personal use and teaching without any further permission.

Become a Fellow of BMJ Case Reports today and you can:

- Submit as many cases as you like

- Enjoy fast sympathetic peer review and rapid publication of accepted articles

Access all the published articles

Re-use any of the published material for personal use and teaching without further permission

Customer Service

If you have any further queries about your subscription, please contact our customer services team on +44 (0) 2071111105 or via email at support@bmj.com.

Visit casereports.bmj.com for more articles like this and to become a Fellow 